\title{
Practice-driven journalism research: Impulses for a dynamic understanding of journalism in the context of its reorganization ${ }^{1}$
}

\author{
Christopher Buschow, Bauhaus-Universität Weimar, Department of Media Management, \\ Faculty of Media, Germany \\ christopher.buschow@uni-weimar.de
}

\begin{abstract}
This paper proposes a practice-theoretical journalism research approach for an alternate and innovative perspective of digital journalism's current empirical challenges. The practice-theoretical approach is introduced by demonstrating its explanatory power in relation to demarcation problems, technological changes, economic challenges and challenges to journalism's legitimacy. Its respective advantages in dealing with these problems are explained and then compared to established journalism theories. The particular relevance of the theoretical perspective is due to (1) its central decision to observe journalistic practices, (2) the transgression of conventional journalistic boundaries, (3) the denaturalization of journalistic norms and laws, (4) the explicit consideration of a material, socio-technical dimension of journalism, (5) a focus on the conflicting relationship between journalistic practices and media management practices, and (6) prioritizing order generation over stability.
\end{abstract}

\section{Keywords}

journalism, journalism theories, practice theory, theory development, digitization

\section{Introduction ${ }^{1}$}

Theory development is typically regarded as an essential driving force for the progress of scientific knowledge. It is primarily comprised of the construction of approaches for responding to newly emerging theoretical and practical problems - to empirical challenges - in a certain field of research (Morrison, 2018). Altered or new theories should help to describe, understand, explain and, if possible, forecast such empirical challenges and propose solutions. In contrast to the natural sciences, theory development in media and communication studies apparently results less from fundamental anomalies in empirical research than from relevant aspects of a research object be-

1 This is a slightly updated and translated version of the German article: Buschow, C. (2018). Journalistik praxistheoretisch betreiben: Impulse für ein dynamisches Verständnis des Journalismus im Kontext seiner Neuordnung. Publizistik, 63(4), 513-534. https:// dx.doi.org/10.1007/s11616-018-0458-5. ing overlooked or even suppressed, from the viewpoint of traditional approaches. Today, against the background of advancing digitization, the question arises as to whether the current changes in the media environment can still be adequately addressed within the range of established theories. This is especially relevant to journalism, since its traditional mass media structures are collapsing over the course of economic, technological and societal changes (Alexander, 2015; Deuze \& Witschge, 2018).

In this paper, I will highlight certain processes of journalism's current reorganization and the empirical challenges they pose, which I aim to address from an alternative theoretical angle. In doing so, I will refer to the family of practice theories that connect to ongoing renewals in journalism studies (Ahva, 2017; Ryfe, 2018; Witschge \& Harbers, 2018), as well as media and communication studies (Couldry, 2004; Pentzold, 2020). These theories have gained popularity in numerous fields of the social sciences, especially because they promise 
innovative perspectives and new conceptualizations of problems. Unlike middle range theories (Merton, 1968), practice theories are not clearly structured, falsifiable systems of hypotheses. In the empirical-pragmatic interpretation I present in this paper, they act more as a 'theoretical toolbox' that enables new types of questions, perspectives and forms of empirical research (Nicolini, 2012, pp. 216-219; Reckwitz, 2002, p. 257). With this, I aim to provide a practice-driven journalism research approach that allows for the reinterpretation of current empirical challenges, especially in journalistic production (Ryfe, 2018). However, I do not explicitly seek to present practice theories in their entirety, deconstruct them critically, conceptually enhance them, or compare different streams of literature.

The paper is structured as follows: In Section 2, central empirical challenges of journalism are briefly summarized, which are primarily initiated by digitization and interpreted as building blocks of its current reorganization. Section 3 drafts an empirical-pragmatic interpretation of practice theories and illustrates their (exemplary) potential for the observation and reinterpretation of the challenges described. Thus, as summarized in Section 4 , a promising perspective on journalism is proposed, one which can provide innovative impulses for the progress of scientific knowledge in the field. This does not mean, however, that established theories should be discarded. Nevertheless, a critical revision seems to be necessary (especially given developments in the field), so that theories of journalism studies do not become an "obstacle to knowledge" (Rühl, 2011, p. 11, my translation).

\section{Empirical challenges: The reorganization of journalism under digitization}

At least four intertwined, partly global problems pose empirical challenges to journalism (Neuberger, 2018; Siles \& Boczkowski, 2012): (1) increasing problems of definition and demarcation in digital media, (2) the rapid development of new technology, (3) difficulties in financing journalism, and (4) a widely-reported crisis of its legitimacy and authority. These empirical challenges have been, as I will illustrate in the following, essentially initiated or advanced by the digitization of today's media environment.

\subsection{Demarcation}

In a media landscape characterized by print and broadcasting, definitional questions of journalism have been primarily a matter of academic controversy. To the extent that the emergence of digital media today enables the participation of every user, with new voices gaining publicity and communication power (Castells, 2009), the formerly academic discussion about journalism's boundaries is becoming increasingly relevant in praxis: who can be considered a journalist today if everyone can publish, and at any time? What distinguishes journalistic actors from other speakers in digital media? What relationship should journalism have with these communicators? The variety of answers to these questions reflects a growing uncertainty on all sides - journalistic profession, users, scholarship - about the phenomena that can still be classified as 'journalistic' (Loosen, 2015, p. 77; Neuberger, 2018, pp. 36-38).

This "identity crisis" (Neuberger, 2018, p. 36, my translation) provokes active boundary work on the part of journalists (Carlson \& Lewis, 2015). Today, the differences between journalism and the forms of public communication that have mostly emerged under conditions of digitization and compete for users' attention are being consciously stressed. For instance, differences between individuals with high levels of publicity and reach (so-called 'influencers'), social networks and their algorithms, citizen journalism, advertising, and corporate communication.

\subsection{Technology}

Due to the rapid development of new (internet) technologies, which are reaching market maturity in increasingly shorter intervals, and due to the growing relevance 
of data and networks in a digitalized media environment, journalism seems to be caught up in a technology race that takes on crisis-like characteristics. Enormous pressure to change and great uncertainties are evident in at least three areas: (1) working methods, (2) products and genres, and (3) (editorial) organization and forms of cooperation.

1. As new technologies make their way into the core of journalism, established ways of working are changed and questioned, while new ones are created (Anderson \& De Maeyer, 2015; Lewis \& Westlund, 2015). Datafication has opened up innovative research and verification possibilities, as well as completely new data journalistic activities (Hermida \& Young, 2019). User data, such as that generated when sharing or commenting on news, also has a great influence when the data traces generated become the basis of journalistic work and control its activities (Tandoc, 2019). Non-human actors are becoming increasingly important for the execution of journalistic activities, such as when computer systems select, present or even generate news (so-called 'automated journalism') (Hermida \& Young, 2019).

2. "Virtual reality", "augmented reality", "speech recognition" and other technologies have opened up potential for modified modes of presentation, genres and completely new media products in digital journalism (Godulla \& Wolf, 2017). Each time, the question arises as to whether journalism should make use of a new technology/platform for the circulation of news, because it has the potential to develop into a new mass medium, or whether it is just hype.

3. As "post-industrial means of production" (Alexander, 2015, p. 17), hardware and software technologies create the basis for new forms of networked cooperation in journalism, which are no longer necessarily bound to traditional workplaces like the newsroom (Anderson, Bell, \& Shirky, 2012).

\subsection{Economy}

The current financial difficulties of journalism have arisen under a digital media economy in which competition for attention has become much fiercer, unlike print and broadcast media (Nielsen, 2016). The long-established business model of the daily newspaper is barely functional under these conditions. Journalistic media products currently only generate small profits, both on the digital advertising and reader markets (Buschow \& Wellbrock, 2019; Picard, 2014).

Since no economically sustainable alternatives to the traditional revenue streams have yet been developed, journalism faces great economic uncertainty. A large number of press publishers are reacting to the economic challenges brought about by digitization by consolidating and reducing costs, and in some cases entire newspapers have been discontinued. Between 2006 and 2013, 40,000 jobs were cut across all the publishers in Germany (Seufert, 2013). In some cases, this has led to atypical employment relationships (Deuze \& Witschge, 2018) and the emergence of new companies and start-ups outside established media structures (Buschow, 2020; Küng, 2015). In this increasingly precarious economic environment, journalism can hardly take place under comparable working conditions to those possible in the mass media structures of the $20^{\text {th }}$ century (Anderson et al., 2012; Deuze \&Witschge, 2018).

\subsection{Legitimacy}

Journalism has recently become the focus of heated controversy about its privileged social position, following (political) attacks. Some parts of the population are questioning its legitimacy, authority and truthfulness, and claiming that there has been a stark drop in quality (Quandt, 2018). Debate is emerging about echo chambers and filter bubbles, which are supposed to be created by communication and datafication on platforms and presumably lead to a fragmentation of audiences and increasing polarization on the spectrum of opinions (Pariser, 2011). 
The empirical data on alleged quality losses is as ambiguous as that on the widely-reported loss of trust and echo chambers / filter bubbles (Neuberger, 2018). At the same time, these debates about legitimacy affect journalism in the already-volatile times that digitization has created. Legitimacy debates are a plausible consequence of new forms of public communication in digital media, which, as indicated in Section 2.1, now fundamentally enable all kinds of 'media critique' (Jarren, 2016).

\section{Theoretical reactions: A practice- driven approach to addressing the empirical challenges of journalism}

The crisis-like developments identified in the previous section can be interpreted as the expression of a reorganization of journalism under the conditions of its digitization (Buschow, 2018). They pose empirical challenges that are acknowledged as relevant both within and outside the academic world. The extent to which a theory can grasp these challenges and deal with them productively is an important criterion for evaluating its performance.

Are established theoretical approaches capable of adequately focusing on the challenges outlined above and proposing productive solutions to them? A substantial number of the approaches still applied in journalism studies today have been developed in the light of historical conditions. Modern research on journalism emerged when many of its research objects (media organizations, newsrooms, employed journalists) were quite homogeneous and distinct. Against this background, empirical research on the professional field of journalism and its actors in particular has been accused of a certain "abstinence from theory", as it takes concepts and categories for granted and applies them without sufficient theoretical reflection (Raabe, 2005, p. 19; Rühl, 2011, pp. 11-12). In a simplified form, the theoretical field of journalism studies can be categorized as follows: on the one hand, theories of middle or small range focus on explaining the emergence of journalistic output by considering influencing factors on different levels or to focus on journalistic mechanisms of content presentation (e.g. news values research, gatekeeping approach, agenda-setting theory). On the other hand, attempts were made - at least in the German-speaking scientific community - to embed research in the socalled 'grand social theories', e. g. in the social systems theory with reference to Niklas Luhmann or in Marx's historical materialism (Loeffelholz \& Quandt, 2005). The epistemological interests of these journalism theories and their mechanisms in the conceptualization of empirical problems are mainly based on the questions and answers of pre-digital journalism, in which its order seemed to be taken for granted, and remained largely unquestioned.

There have thus been increasing signs of a "next generation of journalism theory" (the title of an edited book by Altmeppen, Hanitzsch, \& Schlüter, 2007, my translation). Several authors are concerned that researching journalism with entrenched concepts, traditional terminology and middle range theories based on principles of falsification could suppress novelty in the research area (Ahva, 2017; Deuze \& Witschge, 2018; Ryfe, 2018; Witschge \& Harbers, 2018). Deuze and Witschge (2018, p. 177) have called for "a toolkit that looks at the field as a moving object and as a dynamic set of practices and expectations - a profession in a permanent process of becoming". Such a theoretical toolbox can be developed, as I will illustrate in the following, based on the family of practice theories.

\subsection{Background: An empirical-pragmatic interpretation of practice theories}

Although several heterogeneous approaches are regarded as practice theories, which can be traced back to different fields of origin (sociology, social philosophy, sociology of science, science and technology studies, etc.) and which are clearly distinctive in detail, they are nevertheless connected by a certain "family resemblance" (Reckwitz, 2002, p. 244). ${ }^{2}$

2 Due to the limited scope of this paper and its aim of proposing an 'ideal type' of prac- 
What practice theories have in common is that they develop a novel kind of social ontology through which the world can be experienced in a specific way: their attention is on social practices as fundamental units of analysis, which (from this point of view) form the relevant constituents of everyday human life and the social world (Feldman \& Orlikowski, 2011; Giddens, 1976; Giddens, 1984; Nicolini, 2012; Reckwitz, 2002; Schatzki, Knorr-Cetina, \& von Savigny, 2001; Schatzki, 2002; Schatzki, 2016; Shove, Pantzar, \& Watson, 2012). In essence, social practices can be understood as typical patterns of action, which are enacted regularly, across contexts, at different times and in different places. Although this definition highlights a certain routinization, regularity and stability of social practices, the transformative potential of practices must always be taken into account. Anthony Giddens (1976, p. 102) emphasizes that social practices carry both continuity and renewal: "All reproduction is necessarily production, however, and the seed of change is there in every act which contributes towards the reproduction of any 'ordered' form of social life." Social practices constitute broader social phenomena, the so-called practice constellations (such as organizations, networks or markets) which indicate a certain orderliness of the social (Giddens, 1984; Schatzki, 2016, pp. 5-7).

Even if practice theories always take social practices as their starting point, they by no means only focus on the local, situational actions of actors - unlike classical theories of action or interpretative phenomenological approaches (Giddens, 1976). In addition to an in-depth analysis of individual practices, the aim is to reflect on their structural embedding, on their interweaving and interdependence with other practices, their effects and social consequences in the constitution of wider-reaching phenomena (cf. Bus-

tice theories for use in journalism research, the theoretical and methodological differences between these individual approaches cannot be discussed in detail in the following (for an introduction, see Nicolini, 2012; Reckwitz, 2002; Shove et al., 2012). chow, 2018, pp. 233-235; Nicolini, 2012, pp. 228-235; Schatzki, 2016, pp. 16-23). Social practices thus always remain tied to a trans-situational structure, which provides a backdrop for analysis and can be refocused on again at any time.

Due to their focus, practice theories cannot be meaningfully classified either as action or structural theories: they do not begin with superordinate structures or with the single actions of individuals, but focus on typical patterns of action in a research area and link these with structural conditions and consequences (Giddens, 1984). However, it is the constant, repetitive interaction of action and structure in and through social practices that (re-) produces social order, whose continuous production, perpetuation and eventual disruption are the programmatic core of practice-theoretical research interest. In the understanding of practice theories, social phenomena - including subjects, their mental characteristics and structures - are not axiomatically presupposed by theory but are first and foremost shaped and (re-) produced by social practices (cf. Schatzki 2002, pp. 89-105). To this end, practices 'choose' various (possibly also non-human) actors as carriers and, thus, (re-)producers (cf. Shove et al. 2012, pp. 63-66). The focus of the approaches considered here is therefore less on fixed entities, but rather on fluid processes and the mechanisms through which order is generated. At the same time, theories of practice bear critical potential, such as when they reveal the inequalities and power differences reproduced in praxis and when they question their "reification" - an assumed non-human facticity of human phenomena (cf. Berger \& Luckmann, 1967, p. 88).

In recent years, practice theories have sparked a broad spectrum of novel research in numerous social science disciplines. They are particularly stimulating where traditional theories, categorizations and terminology have reached the limits of dynamic fields of investigation and empirical challenges. This is because practice theories denaturalize the theoretical entities derived from previous research, the seemingly self-evident definitional 
instruments and their established (actor) categories which have been consolidated over longer periods. These can, therefore, suppress the observation of changes in journalism (Domingo, Masip, \& Costera Meijer, 2015, p. 64).

Practice theories should thus not be understood as permanent knowledge, from which hypotheses can be empirically derived, tested and possibly falsified. They are more of a theoretical point of departure from which an altered understanding of the current challenges facing journalism is possible, and from which innovative research can be initiated. Nicolini (2012) showed that such an empirical-pragmatic interpretation of practice theories is practicable when he proposed a "toolkit approach" (pp. 213-241) that allows for new questions and the reinterpretation of empirical challenges (also see Reckwitz, 2002, pp. 257-259). Such a toolbox includes the characteristics of the practice theories outlined in this section: a specific conceptual instrument, basic units of analysis, and assumptions about processes and mechanisms in the constitution of social order.

\subsection{The performance of practice theories in conceptualizing the reorganization of journalism}

It is apparent that the interpretation of practice theories I have developed here is capable of conceptualizing the current reorganization of journalism. A primacy of the empirical, a focus on the accomplishment of typical patterns of action, and a processual, dynamic understanding of a constantly evolving order (instead of fundamental stability) are the important advantages of an analytical perspective that seeks to grasp the increasingly fluid institutional context of journalism. ${ }^{3}$

In terms of practice theories, journalism is always 'in the making'. It is con-

3 These characteristics prove to be advantages with regard to the specific objectives of this paper - to provide a new research perspective for the empirical challenges of journalism outlined above. Other characteristics of practice theories, which could not be discussed here, may be considered advantages for other objectives (see also Section 4). stituted, perpetuated and changed as a practice constellation solely through the enactment of social practices. What is considered journalism is taken from the ongoing praxis itself - from what the actors regularly do across contexts, and themselves define as journalism. At the same time, it is newly empiricized: journalism is what is established as 'journalism' both in and through social practices (Ahva, 2017; Buschow, 2018; Raabe, 2005; Ryfe, 2018; Witschge \& Harbers, 2018). The question of which social practices to focus on is an empirical one, which does not necessarily have to be decided before the start of the research process. With such an open and exploratory procedure, unexpected findings that have not been specifically looked for beforehand can be captured.

In the following, the potential of a practice-driven journalism research approach will be explained, with reference to central problems of journalism's reorganization, as outlined in Section 2. The main focus will be on demonstrating the extent to which a practice-theoretical approach proves to be useful and innovative, in order to productively address the four empirical challenges. Does the practice-theoretical perspective provide alternative perspectives that stand out from the established approaches of journalism studies? Does it open up promising starting points for new questions and empirical investigations?

\subsubsection{Demarcation: Capturing new practices and actors by deliberately crossing borders}

How can the proposed perspective help to overcome the identity crisis of journalism outlined in Section 2.1? The answer to this question is sobering: practice theories are quite unsuitable for making a tangible distinction between media contexts that could support journalists in drawing boundaries with neighboring communication phenomena, such as PR or propaganda. The expectation is already at the core of the idea that practice constellations have blurred often precarious boundar- 
ies. ${ }^{4}$ Anthony Giddens (1984, p. 165), for instance, highlights that "it is important to re-emphasise that the term 'social system' should not be understood to designate only clusters of social relations whose boundaries are clearly set off from others. The degree of 'systemness' is very variable...". The proposed approach hence stands in stark contrast to system-theoretical principles, which intend to clearly delineate the journalistic system by means of specific functional attributions (cf. Raabe, 2005, pp. 48-75). This results in at least four promising research perspectives that hold potential for conceptual innovations and impulses in journalism studies.

As outlined above, all practice theories start with a focus on social practices, i.e. the typical patterns of action in a research area. From a research strategic point of view, normative classifications such as "journalistic programs" that are grounded in past studies do not a priori prescribe the aspects to be examined (Buschow, 2018, pp. 119-121). Instead, it is primarily through empirical research that the practices that produce the social phenomenon of 'journalism' are exposed. Therefore, even in established work environments like the newsroom, the established social praxis of everyday news work becomes visible, along with the (possible new) activities that were not dealt with by previous research, or only very marginally (Ahva, 2017). Through the practice-theoretical lens, 'boundary management' (the distinction between and drawing of boundaries; see Section 2.1) becomes recognizable as a journalistic practice that exerts a decisive influence on the emergence of journalism as a practice constellation, just like

4 From my point of view, a practice-driven journalism research approach does not intend to completely 'erode' the limits of its research object (Ahva, 2017; Ryfe, 2018). It is rather about breaking with what I call 'definitional orthodoxy': Practice-driven journalism research differs from such approaches that in a traditional ("orthodox") way very narrowly define the spectrum of journalistic actors and thus exclude important research objects from whose investigation these approaches would have empirically benefited. the well-established practices of investigating or selecting in newsrooms that were usually examined in journalism studies (Buschow, 2018, p. 120; Lewis \& Westlund, 2015, pp. 28-33). The example emphasizes the extent to which the practice-driven research approach can identify new or previously marginalized patterns of action in the traditional work environment.

Furthermore, practice theories open up an innovative perspective, because they do not adopt the often value-laden debates of demarcation, but quite deliberately exceed the boundaries of the established set of actors in journalism. Past and empirical studies on the professional field of journalism, which are mainly informed by systems theory, usually start with a few narrowly-focused categories of actors, such as 'press publishers', 'broadcasters' or 'full-time journalists'. Practice theories are not based on these traditional categories. Thus, in principle, a greater variety of actors as carriers of journalistic practices can be examined: journalism research can then be applied to organizations such as start-ups or research networks, as well as to non-human, sociotechnical actors (algorithms, robots or code), which now carry out activities previously performed by humans (Buschow, 2018, pp. 330-335).

Seen through the lens of practice theories, the normative premises or laws of journalism also appear in a different light. They are often interpreted as preceding or superordinate to social praxis, and demarcations are thus established on their basis, for instance in media systems research or media law (cf. Witschge \& Harbers, 2018, p. 107). From the perspective followed here, however, these norms and laws, which are in a certain respect 'reified' (see Section 3.1), must be understood as social constructions and as condensed, codified results of previous social praxis.

Practice theories can be applied in order to explore the mobility and strategic transportation of journalistic practices into new contexts - together with the consequences for the practices concerned, the practice constellations and their boundaries. They promise insights into the way in which practices are 're-localized' beyond 
pre-defined borders. In doing so, it is possible to trace the extent to which journalistic practices are removed from their original (organizational) contexts and copied or imitated in new environments, such as in corporate publishing or in the so-called 'newsrooms' of political parties, with the aim of legitimizing the activities undertaken there, or creating brand value (Neuberger, 2018, pp. 37-38).

Since established practices, traditional actors and reified norms do not mark the boundaries of the research area, the practice-theoretical conceptualization remains open to grey areas and niches which can anticipate future steps in the development of journalism, and showcase possible futures (Strippel et al., 2018, p. 12-13). With reference to practice theories, a much wider spectrum of journalistic activities and actors can be registered when compared to the established theories, which often start 'top-down' from existing organizations, individuals or activities. Practice theories' sensitivity to variety and diversity promises to tie journalism studies closer to its research object, which in its richness is experienced in a new, empirical-explorative way (Couldry 2004; Deuze \& Witschge, 2020; Witschge \& Harbers, 2018). In practice-driven journalism research, the empirical challenges of demarcating journalism are therefore to be reinterpreted as a promising starting point for empirical research to transgress certain, supposedly solid boundaries of journalism.

\subsubsection{Technology: Understanding technology as a constitutive element of social practices}

There is no agreement within the family of practice theories as to whether social practices are the basic building blocks of social life, or whether practices are to be traced back to other components. If the latter view is held, then interpretative, normative and material components of social practices are usually differentiated between (Reckwitz, 2002; Shove et al., 2012). Since the practice-theoretical approach takes all three analytical dimensions into account, it integrates previously separate social-the- oretical perspectives. It not only allows individual rules of journalism (professional and legal norms, quality standards, role attributions, public image, etc.) or isolated resources (tools, technologies and infrastructure, business models, etc.) to be examined selectively, but also focuses on the interaction of all these components in and through the journalistic practices that integrate them (Buschow, 2018, pp. 121-125). Such an integrative, anti-reductionist approach clearly distinguishes practice theories from classical social theories, which often focus on a single social dimension, such as economic resources or cultural discourse (cf. Giddens, 1981, p. 26).

The material world (bodies, natural things, artifacts, etc.) and technology are seen to have an essential meaning in the constitution of social practices. ${ }^{5}$ Nevertheless, practice theories do not understand technology as a seemingly autonomous, natural resource that, once invented, suddenly creates upheavals in journalism. The appropriation and application of technologies within social practices (such as the journalistic practices of investigating, selecting, and producing) is only possible and meaningful because of the carrier's knowledge of these practices. Actors must take possession of technology by 'putting it into practice', and institutionalize its use before it can actually lead to renewal in a practice constellation (Feldman \& Orlikowski, 2011, pp. 1247-1249).

The conceptualization of technology as a resource to be integrated within journalistic practices demystifies, to a certain extent, claims of the technology-induced pressure for change presented in Section 2.2. It avoids two fundamental theoretical problems (Alexander, 2015): a deterministic understanding of technology as an external, largely independent force that quasi-automatically triggers change, and a voluntaristic perspective of technology as a genuine positive tool that en-

5 Controversies within the family of practice theories arise from the question whether objects and things can be understood as independent agents ("actants") (e.g. Schatzki, 2002, pp. 190-210). 
ables journalists to work more freely and self-determinedly. From the perspective of practice theories, both approaches, some of which are represented in established research (cf. Witschge \& Harbers, 2018, p. 109), must be rejected as reductionist. The perspective proposed here thus differs clearly from a technology-dependent or a technology-skeptical journalism research approach.

From the perspective of practice theories, specific questions can then be raised: what significance do individual technologies have as resources within the accomplishment of a specific journalistic practice? With new technologies, how does this practice differ from its past conditions? How do the new technologies find their way into journalistic practices, and what other components (e.g. discourses on their usage) do they carry into the practice constellation of journalism (cf. Shove et al., 2012, pp. 21-41)? An exemplary result of the influx of technology is the phenomenon of data journalism, understood from a practice-theoretical perspective as an integration of resources and discourses from data analytics, statistics, computer and hacker culture in journalistic praxis. The same applies to drone or sensor journalism, by means of which previously separate practice constellations (aviation, computer science, robotics) are finding their way into journalism.

The analytical gain of this perspective is also visible in the influence of technology on news production structures and organizational forms of journalism. New software and hardware technologies, as components of journalistic practices, allow for the joint management of these practices as virtually mediated, without necessarily presupposing the same physical location or simultaneous activities on the part of their carriers (Knorr-Cetina \& Bruegger, 2002). Based on the introduction of the telegraph in the $19^{\text {th }}$ century, Anthony Giddens addressed this phenomenon with reference to the concept of "time-space distanciation" (Giddens, 1991, pp. 23-27). Today, however, technologies in social practices become even more decisive for the constitution of de- localized, disintegrated and networked forms of journalistic work (Buschow, 2018, pp. 335-341). The analytical focus on the procedural nature of technology and on its role as a component of social practices provides an enriching perspective for contemporary journalism research.

\subsubsection{Economics: Unbundling the tense interrelationship between journalism and media management} Unsurprisingly, practice theories do not succeed in formulating prescriptive recommendations for the development of financing alternatives in journalism that could be used to solve the economic difficulties outlined in Section 2.3. Rather, the approach advocated here presents economic problems in a new light. They are taken as opportunities to unravel the significant and tense interrelationship between journalism and media management (e.g. Altmeppen, 2006; Bachmann, 2017). In this way, practice theories sensitize us to the fact that economic conditions always have both a restrictive and an enabling influence on journalism. This distinguishes them explicitly from system theories, in which it is sometimes argued that journalism has 'built its organizations'. The fact that clearly economically-motivated media companies (cf. Ludwig, 1999) created these organizations under specific conditions is neglected here. From a practice-theoretical point of view, the disciplinary separation of 'journalism' and 'media management' is recognizable as an artificial juxtaposition (especially under current market conditions and the competition for attention) which sometimes conceals certain power relations (Knoche, 2014). Unlike approaches based on Marx, however, in theories of practice, economic conditions are not understood as inescapable constraints, but as media management practices that are an integral part of journalism and which should not have been given conceptual precedence from the very beginning.

From a practice-theoretical perspective, the mutual influence of management practices and journalistic practices, their concatenation and interdependence, and 
the social effects associated with them can be seen very clearly (Winter \& Buschow, 2017). Media management practices determine the respective business models for financing journalism. Just like technology (see Section 3.2.2), business models are presented as components of journalistic practices. In this context, advertising financing has different effects on the implementation of journalistic practices to financing primarily through subscriptions. As practice-theoretical research on newly founded organizations in journalism shows, the coupling of these start-ups with new sources of financing and with changed business models has a decisive influence on the type of journalism produced (Buschow, 2018, pp. 344-346). In order to attract venture capital financing, for instance, start-ups must align their journalistic practices with the expectations of their investors (Buschow, 2018, pp. 272-275). The practice constellations, which emerge through the interlocking of journalistic practices and media management practices, influence the function and the goals that start-ups combine with their journalistic products, as well as, presumably, the image of their social role and journalistic output (Buschow, 2018, p. 357).

The consideration of media management practices in general and of business models as components of journalistic practices appears, then, to be a promising undertaking for journalism that wants to take appropriate account of the economic upheavals in its subject area, without necessarily assuming a primacy of the economic realm.

\subsubsection{Legitimacy: Applying controversies as episodes of journalism's permanent becoming}

Practice theories alter perspectives on the frequently discussed crisis of journalism's legitimacy (see Section 2.4). From a practice-driven viewpoint, these discourses underline the fact that journalism is not a fixed, reified entity, but rather constantly 'in the making' through the enactment of social practices (Deuze \& Witschge, 2018, p. 169). Numerous individual and corporate actors participate (more or less con- sciously) in the constitution of journalism, such as journalists, media managers, users, companies and political parties. The social praxis of journalism is neither the result of the efforts of certain individuals or partial groups nor the result of some anonymous force which works behind the backs of the actors ('invisible hand', historical laws, etc., as assumed in some grandiose social theories). Neither is journalism a "rational product" (Park, 1923, p. 273) which is planned or determined by these mechanisms. This is particularly evident today under the conditions of digital, networked media, and was already a topic of the sociological Chicago school around Robert E. Park, who emphasized:

\footnotetext{
The press, as it exists, is not, as our moralists sometimes seem to assume, the wilful product of any little group of living men. On the contrary, it is the outcome of an historic process in which many individuals participated without foreseeing what the ultimate product of their labors was to be. The newspaper [...] is not wholly a rational product. No one sought to make it just what it is. In spite of all the efforts of individual men and generations of men to control it and to make it something after their own heart, it has continued to grow and change in its own incalculable ways. (Park, 1923, p. 273).
}

Against the backdrop of fierce media critique (which may be based on false empirical assumptions, see Section 2.4, but exemplarily illustrates the influence of numerous actors in the constitution of journalism), the practice-theoretical perspective proves useful for grasping episodes of continuous generation, stabilization and disruption of journalism's order.

From this, the following research opportunities arise (among others): by specifically focusing on the emergence of order, practice-driven journalism research can observe how new concepts of journalism are developed in response to debates on its legitimacy and quality. It can also understand these new concepts as the results of power struggles between actors. In doing so, it investigates the actors' 
vested interests, means of power and (material) resources, as I have shown in a reconstruction of the debate on an ancillary copyright for press publishers in Germany (Buschow, 2012). Finally, the perspective allows for the reconstruction of the extent to which (individual and corporate) actors are 'manufactured' into a specific role e.g. as a journalist or journalistic organization - through their enactment of certain practices in the first place.

\section{Conclusion}

Practice theories understand journalism as a social phenomenon that can be grasped by means of the social practices that are recursively (re-)produced in their enactment over time and space. In this paper, I have argued that the definitional, technological, economic and legitimation-related empirical challenges of journalism, which arose primarily in the context of its digitization, appear in a new light from such a perspective and can thus be dealt with more productively. On this basis, the previous chapters outlined points of departure for alternative questions and empirical perspectives. The particular relevance and specific advantages of a theoretical perspective that understands journalism as social praxis primarily result from the following characteristics:

1. Central decision to observe journalistic practices: A relatively impartial, inductive empirical approach to journalistic practices can also capture such patterns of action that - unlike the 'standard practices' described in traditional journalism studies - have not been the focus of previous research.

2. Transgression of conventional boundaries of journalism: An initial focus on journalistic practices decentralizes established sets of actors, so that even marginal actors, niche phenomena and contexts formerly regarded as distant from journalism attract research attention - in the sense of "theorizing journalism from the ground up" (Deuze \& Witschge, 2018, p. 169).
3. Denaturalization of journalistic norms and laws: The constitution of social praxis through constant (re-)production explains apparently reified norms and laws of journalism as the results of previous social practices, which, as Rühl (1980) states, are not "[categories] for the essence of journalism that [are] fixed forever, unchangeable" (p. 327, my translation).

4. Consideration of a material, sociotechnical dimension of journalism: Practice theories also emphasize the material dimension of social life. They emphasize the fundamental intertwining of technology with journalistic practices, and refer to the possible agency of technology in journalism.

5. Conflicting relationship between journalistic practices and media management practices: By researching the interconnectedness of social practices, the collision of practices - for instance, between journalism and media management - can be grasped and examined with regard to their (intended and unintended) effects.

6. Prioritizing order generation over stability: By taking into account the constitutional mechanisms of order generation in journalism, practice theories sensitize us to the fact that work on journalism is always carried out by numerous heterogeneous actors, who have often been given insufficient consideration in research.

Despite these strengths, the application of practice theories will hardly solve all the challenges of contemporary journalism (research). Above all, practice theories do not make prescriptive recommendations that would offer clear solutions to concrete problems (see Shove et al., 2012, pp. 162164). In the interpretation presented here, they form an alternative perspective for the exploration of journalism, from which its problems and challenges appear in a different light and can be reflected upon in a new way (Nicolini, 2012; Shove et al., 2012).

Practice theories have been criticized on various occasions. Among the prob- 
lems identified are an investigation of social practices that mostly relies on enactment in the field itself, the risk of following a definitional relativism that puts the normative foundations of journalism at stake, and a theoretical bias that could underestimate the stability of order. Anderson (2020) has recently criticized how practice-driven journalism studies "does not do enough to explain how media actually matter for culture and politics in the early $21^{\text {st }}$ century" (p. 349), particularly as it does not take sufficient account of media content. This criticism must be adequately reflected upon in practice-driven journalism research. It points to the fact that the field needs a rich pluralism of theories, so that the blind spots of practice theories become visible and can be addressed with alternative approaches (Anderson, 2020; Steensen \& Ahva, 2015).

In this paper, I have developed a simplified understanding of practice theories as a theoretical toolbox for new perspectives and alternate conceptualizations of problems in journalism studies. Further accentuations (e.g. the body-bound nature of social praxis, or the tacit knowledge inscribed in practices) and controversies within the family of practice theories could not be taken up from the empirical-pragmatic understanding presented here. With few exceptions, there was no occasion in this paper for a systematic comparison of practice theories in relation to more established social theories.

Where can practice-driven journalism research start in empirical investigations? Several points of departure are conceivable: it can start out from a single journalistic practice, which is captured in depth, followed over space and time, and examined with regard to changes of (several of) its components ("follow the elements of practice"; Shove et al., 2012, p. 22). It can focus on concrete 'sites of the social' (Schatzki, 2002), for instance on established newsrooms or news start-ups, which, of course, always have to be regarded as provisional products of social praxis (Ahva, 2017). ${ }^{6} \mathrm{Fi}$ -

6 Here, however, there is a risk of defining and 'cutting' practices in a classical social nally, it can analyze the linkage of practices into broader practice constellations, and thus trace the genesis of newly-emerging production networks that have so far played only a minor role in (German) journalism studies (Buschow, 2018). As social science methods, primarily qualitative (participant) observations and news work ethnographies prove to be adequate, since they allow for the following of social practices in their actual enactment (Ryfe, 2018). Nevertheless, their application is always limited when journalistic practices, as virtually mediated practices, are carried out neither at the same time nor in the same place, something which seems increasingly to be the case (Anderson, 2011). Here, approaches of "multi-sited ethnography" (Marcus, 1995) can be considered. For special research contexts (e.g. media companies where the implementation of (some) practices is the subject of in-depth discursive reflection), non-observational, verbal methods such as survey studies (with 'practitioners' or in 'communities of practice') and document analyses may also be viable (Hitchings, 2012). ${ }^{7}$

It was the German journalism scholar Manfred Rühl who emphasized that scholars alone are in the position "to enter new territory that is difficult to access, i.e. to think about journalism other than only in terms of the categories and concepts that have been handed down through history" (Rühl, 1980, p. 13, my translation). Today's research cannot fall behind this conviction: it will be of vital importance for future-oriented journalism studies. The practice-driven approach outlined in this paper proposes a fertile point of departure to address Manfred Rühl's call under the current dynamics of digitization.

theoretical sense: Practices always cross the boundaries of organizations; a too narrow perspective fails to reveal this interwovenness.

7 For an overview of practice-theoretical research strategies, see Bueger \& Gadinger (2018, pp. 131-161), Jonas, Littig \& Wroblewski (2017), Nicolini (2012, pp. 213-242) and Ryfe (2018). 


\section{Acknowledgements}

I want to express my gratitude to Springer Nature and the editor of Publizistik, Prof. Dr. Gunter Reus, for the permission to republish this work. I would like to acknowledge the reviewers as well as the guest editors of this Thematic Section who highly contributed to the further development of this article.

\section{References}

Ahva, L. (2017). Practice theory for journalism studies: Operationalizing the concept of practice for the study of participation. Journalism Studies, 18(12), 1523-1541. https://doi.org/doi:10.1080/146167 0x.2016.1139464.

Alexander, J. C. (2015). The crisis of journalism reconsidered: Cultural power. Fudan Journal of the Humanities and Social Sciences, 8(1), 9-31. https://doi.org/doi:10.1007/ s40647-014-0056-5.

Altmeppen, K.-D. (2006). Journalismus und Medien als Organisationen: Leistungen, Strukturen und Management [Journalism and media as organizations: Performance, structures and management]. Wiesbaden: Springer VS.

Altmeppen, K.-D., Hanitzsch, T., \& Schlüter, C. (Eds.). (2007). Journalismustheorie: Next Generation. Soziologische Grundlegung und theoretische Innovation [Next generation of journalism theory: Sociological foundation and theoretical innovation]. Wiesbaden: VS.

Anderson, C. W. (2011). Blowing up the newsroom: Ethnography in an age of distributed journalism. In D. Domingo \& C. Paterson (Eds.), Making online news - Volume 2: Newsroom ethnography in the second decade of internet journalism (pp. 151-160). Bern: Peter Lang.

Anderson, C. W. (2020). Practice, interpretation, and meaning in today's digital media ecosystem. Journalism \& Mass Communication Quarterly, 97(2), 342-359. https://doi. org/doi:10.1177/1077699020916807.

Anderson, C. W., \& De Maeyer, J. (2015). Introduction: Objects of journalism and the news. Journalism, 16(1), 3-9. https://doi. org/doi:10.1177/1464884914545728.

Anderson, C. W., Bell, E., \& Shirky, C. (2012). Post industrial journalism: Adapting to the present. Columbia Journalism School/ Tow Center for Digital Journalism. https:// academiccommons.columbia.edu/ doi/10.7916/D8N01JS7.

Bachmann, P. (2017). Medienunternehmen und der strategische Umgang mit Media Responsibility und Corporate Social Responsibility [Media companies and the strategic approach to media responsibility and corporate social responsibility]. Wiesbaden: SpringerVS.

Berger, P. L., \& Luckmann, T. (1966). The social construction of reality: A treatise in the sociology of knowledge. New York: Doubleday.

Bueger, C., \& Gadinger, F. (2018). International practice theory (2nd ed.). London: Palgrave Macmillan.

Buschow, C. (2012). Strategische Institutionalisierung durch Medienorganisationen. Der Fall des Leistungsschutzrechtes [Strategic institutionalization by media organizations: The case of the ancillary copyright]. Köln: Herbert von Halem.

Buschow, C. (2018). Die Neuordnung des Journalismus. Eine Studie zur Gründung neuer Medienorganisationen [Re-organizing journalism: A study on the formation of new media organizations]. Wiesbaden: Springer VS.

Buschow, C. (2020). Why do digital native news media fail? An investigation of failure in the early start-up phase. Media and Communication, 8(2), 51-61. https://doi.org/ doi:10.17645/mac.v8i2.2677.

Buschow, C., \&Wellbrock, C. (2019). Money for nothing and content for free? Willingness to pay for digital journalism. Düsseldorf: Landesanstalt für Medien NRW.

Carlson, M., \& Lewis, S. C. (2015). Boundaries of journalism: Professionalism, practices and participation. Abingdon: Routledge.

Castells, M. (2009). Communication power. Oxford: Oxford University Press.

Couldry, N. (2004). Theorising media as practice. Social Semiotics, 14(2), 115-132. https:// doi.org/doi:10.1080/1035033042000238295.

Deuze, M., \&Witschge, T. (2016). What journalism becomes. In C. Peters \& M. Broersma 
(Eds.), Rethinking journalism again. Societal role and public relevance in a digital age (pp. 115-130). Abingdon: Routledge.

Deuze, M., \&Witschge, T. (2018). Beyond journalism: Theorizing the transformation of journalism. Journalism, 19(2), 165-181. https://doi.org/ doi:10.1177/1464884916688550.

Domingo, D., Masip, P., \& Costera Meijer, I. (2015). Tracing digital news networks: Towards an integrated framework of the dynamics of news production, circulation and use. Digital Journalism, 3(1), 53-67. https://doi.org/doi:10.1080/21670811.20 14.927996.

Feldman, M. S., \& Orlikowski, W. J. (2011). Theorizing practice and practicing theory. Organization Science, 22(5), 1240-1253. https://doi.org/doi:10.1287/ orsc. 1100.0612 .

Giddens, A. (1976). New rules of sociological method. London: Hutchinson.

Giddens, A. (1981). A contemporary critique of historical materialism. Volume 1: Power, property and the state. Berkeley: University of California Press.

Giddens, A. (1984). The constitution of society: Outline of the theory of structuration. Berkeley: University of California Press.

Giddens, A. (1991). Modernity and Self-Identity: Self and Society in the Late Modern Age. Cambridge: Polity.

Godulla, A., \&Wolf, C. (2017). Digitale Langformen im Journalismus und Corporate Publishing [Digital long forms in journalism and corporate publishing]. Wiesbaden: Springer VS.

Hermida, A., \& Young, M. L. (2019). Data journalism and the regeneration of news. London: Taylor \& Francis.

Hitchings, R. (2012). People can talk about their practices. Area, 44(1), 61-67. https://doi. org/doi:10.1111/j.1475-4762.2011.01060.x

Jarren, O. (2016). Nicht Daten, sondern Institutionen fordern die Publizistik- und Kommunikationswissenschaft heraus [It's not data but institutions that challenge journalism and communication science]. Publizistik, 61(4), 373-383. https://doi. org/doi:10.1007/s11616-016-0301-9.

Jonas, M., Littig, B., \&Wroblewski, A. (Eds.) (2017). Methodological reflections on practice oriented theories. Cham: Springer International.

Knorr-Cetina, K., \& Bruegger, U. (2002). Global microstructures: The virtual societies of financial markets. American Journal of Sociology, 107(4), 905-950. https://doi. org/doi:10.1086/341045.

Küng, L. (2015). Innovators in digital news. London: I.B. Tauris.

Lewis, S. C., \&Westlund, O. (2015). Actors, actants, audiences, and activities in cross-media news work. Digital Journalism, 3(1), 19-37. https://doi.org/doi:10.108 0/21670811.2014.927986.

Loeffelholz, M., \& Quandt, T. (2005). Journalism theory: Developments in German speaking countries. Ecquid Novi: African Journalism Studies, 26(2), 228-246. https://doi. org/doi:10.1080/02560054.2005.9653332.

Loosen, W. (2015). The notion of the "blurring boundaries": Journalism as a (de)differentiated phenomenon. Digital Journalism, 3(1), 68-84. https://doi.org/doi:10.1080/21 670811.2014 .928000 .

Marcus, G. E. (1995). Ethnography in/of the world system: The emergence of multisited ethnography. Annual Review of Anthropology, 24(1), 95-117. https://doi.org/ doi:10.1146/annurev.an.24.100195.000523.

Merton, R. K. (1968). Social theory and social structure. Towards the codification of theory and research. New York: Free Press.

Morrison, M. (2018). Building theories: Strategies not blueprints. In E. Ippoliti \& D. Danks (Eds.), Building theories. Heuristics and hypotheses in sciences (pp. 21-43). Cham: Springer International.

Neuberger, C. (2018). Journalismus in der Netzwerköffentlichkeit [Journalism in the networked public sphere]. In C. Neuberger, C. Nuernbergk, \& M. Rischke (Eds.), Journalismus im Internet. ProfessionPartizipation - Technisierung [Journalism online : Profession - participation - technification] (2nd ed., pp. 11-80). Wiesbaden: SpringerVS.

Nicolini, D. (2012). Practice theory, work, and organization: An introduction. Oxford: Oxford University Press.

Nielsen, R. (2016). The business of news. In A. Hermida, D. Domingo, C. W. Anderson, \& T. Witschge (Eds.), The Sage handbook of 
digital journalism (pp. 51-67). Thousand Oaks: Sage.

Pariser, E. (2011). The filter bubble: What the internet is hiding from you. Amsterdam: Amsterdam University Press.

Park, R. E. (1923). The natural history of the newspaper. American Journal of Sociology, 29(3), 273-289.

Pentzold, C. (2020). Jumping on the practice bandwagon: Perspectives for a practice-oriented study of communication and media. International Journal of Communication, 14(1), 2964-2984.

Picard, R. G. (2014). Twilight or new dawn of journalism? Journalism Studies, 15(5), 500-510. https://doi.org/doi:10.1080/1461 670x.2014.895530.

Quandt, T. (2018). Dark participation. Media and Communication, 6(4), 36-48. https:// doi.org/doi:10.17645/mac.v6i4.1519.

Raabe, J. (2005). Die Beobachtung journalistischer Akteure [The observation of journalistic actors: Options for empirical-critical journalism research]. Wiesbaden: Springer VS.

Reckwitz, A. (2002). Toward a theory of social practices: A development in culturalist theorizing. European Journal of Social Theory, 5(2), 243-263. https://doi.org/ doi:10.1177/13684310222225432.

Rühl, M. (1980). Journalismus und Gesellschaft. Bestandsaufnahme und Theorieentwurf [Journalism and society: Review of the current situation and theory development]. Mainz: v. Hase \& Koehler.

Rühl, M. (2011). Journalistik und Journalismen im Wandel. Eine kommunikationswissenschaftliche Perspektive [Journalism research and journalism in transition: $A$ communication science perspective]. Wiesbaden: Springer VS.

Ryfe, D. M. (2018). A practice approach to the study of news production. Journalism, 19(2), 217-233. https://doi.org/ doi:10.1177/1464884917699854.

Schatzki, T. R. (2002). The site of the social: A philosophical account of the constitution of social life and change. University Park: Penn State University Press.

Schatzki, T. R. (2016). Keeping track of large phenomena. Geographische Zeitschrift, 104(1), 4-24.
Schatzki, T. R., Knorr-Cetina, K., \& von Savigny, E. (2001). The practice turn in contemporary theory. Abingdon: Routledge.

Seufert, W. (2013). Die deutsche Medienwirtschaft: Wachstums- oder Krisenbranche? Produktion und Nachfrage nach Medienprodukten seit 1991 [Media industry in Germany: Growth or crisis? - Production and demand for media products since 1991]. MedienWirtschaft, 10(4), 20-37. https://doi.org/doi:10.15358/1613-06692013-4-20.

Shove, E., Pantzar, M., \& Watson, M. (2012). The dynamics of social practice: Everyday life and how it changes. Thousand Oaks: Sage.

Siles, I., \& Boczkowski, P. J. (2012). Making sense of the newspaper crisis: A critical assessment of existing research and an agenda for future work. New Media \& Society, 14(8), 1375-1394. https://doi.org/ doi:10.1177/1461444812455148.

Steensen, S., \& Ahva, L. (2015). Theories of journalism in a digital age: An exploration and introduction. Journalism Practice, 9(1), 1-18. https://doi.org/doi:10.1080/1751278 6.2014.928454.

Strippel, C., Bock, A., Katzenbach, C., Mahrt, M., Merten, L., Nuernbergk, C., Pentzold, C., Puschmann, C., \& Waldherr, A. (2018). Die Zukunft der Kommunikationswissenschaft ist schon da, sie ist nur ungleich verteilt. Eine Kollektivreplik [The future of communication science is already here, it is just not evenly distributed: A collective response]. Publizistik, 63(1), 11-27. https://doi.org/doi:10.1007/s11616-0170398-5.

Tandoc, E. C. (2019). Analyzing analytics: Disrupting journalism one click at a time. Abingdon: Routledge.

Winter, C. \& Buschow, C. (2017). Die neue Komplexität vernetzten Medienmanagements. Theorieinnovationen für die Medienmanagementforschung [The new complexity of networked media management: Theory innovations for media management research]. Medien \& Kommunikationswissenschaft, 65(3), 591-612. https://doi.org/ doi:10.5771/1615-634x-2017-3-591.

Witschge, T., \& Harbers, F. (2018). Journalism as practice. In T. P. Vos (Ed.), Journalism (pp. 105-123). Berlin: De Gruyter. 